\title{
Economic empowerment based on the strengthening of social capital in the implementation of village-owned enterprises
}

\section{Pemberdayaan ekonomi berbasis penguatan modal sosial dalam pelaksanaan Badan Usaha Milik Desa (BUMDes)}

\author{
Leylia Khairani ${ }^{* *}$, Ramlan Ramlan², \& Delyana Rahmawany Pulungan ${ }^{3}$ \\ ${ }^{1}$ Master of Communication Sciences, University of Muhammadiyah Sumatera Utara \\ ${ }^{2}$ Faculty of Law, University of Muhammadiyah Sumatera Utara \\ ${ }^{3}$ Departement of Management, Faculty of Economic and Business, \\ University of Muhammadiyah Sumatera Utara \\ Address: 1,2,3 Jalan Kapten Muchtar Basri 3, Medan, North Sumatera, Indonesia 20238 \\ E-mail: leyliakhairani@umsu.ac.id
}

Article History: Received 7 November 2019; Accepted 14 March 2021; Published Online 20 April 2021

\begin{abstract}
Village-owned enterprises or Badan Usaha Milik Desa (BUMDes) is currently trying to realize Indonesia's development from the periphery by strengthening villages' unitary framework state. However, BUMDes in North Sumatera have not utilized the potential of natural resources and the village's potential. This study aims to reveal forms of economic empowerment based on strengthening social capital in implementing BUMDes. This study uses qualitative method research and the data were obtained through in-depth interviews to determine citizens' involvement and participation in developing of BUMDes. This study found that community economic empowerment through the implementation of BUMDes in Mandailing Natal Districts reveals several elements of the role of social capital. First, the involvement and participation of the community which is quite large. Second, relationships between BUMDes managers, village leaders, and community members in the implementation of BUMDes are built based on the social system and cultural values of the Mandailing community. Third, social norms and community beliefs refer to the social system and cultural values of the Mandailing community. Social capital that has been built through the social and cultural system strengthens trust in village-owned enterprises governance as an effort to empower the community's economy in Mandailing Natal.
\end{abstract}

Keywords: economic empowerment; leadership; social capital; village-owned enterprises

\begin{abstract}
Abstrak
Badan Usaha Milik Desa (BUMDes) saat ini berusaha mewujudkan pembangunan Indonesia dari pinggiran dengan memperkuat kerangka negara kesatuan desa. Namun, BUMDes di Sumatera Utara belum memanfaatkan potensi sumber daya alam dan potensi desa. Penelitian ini bertujuan untuk mengungkap bentuk pemberdayaan ekonomi berbasis penguatan modal sosial dalam implementasi BUMDes. Penelitian ini menggunakan metode penelitian kualitatif dan datanya diperoleh melalui wawancara mendalam untuk mengetahui keterlibatan dan partisipasi warga dalam pengembangan BUMDes. Studi ini menemukan bahwa pemberdayaan ekonomi masyarakat melalui implementasi BUMDes di Kabupaten Mandailing Natal mengungkapkan beberapa elemen peran modal sosial. Pertama, keterlibatan dan partisipasi masyarakat yang cukup besar. Kedua, hubungan antara pengelola BUMDes, pimpinan desa, dan anggota masyarakat dalam pelaksanaan BUMDes dibangun berdasarkan sistem sosial dan nilai budaya masyarakat Mandailing. Ketiga, norma sosial dan kepercayaan masyarakat mengacu pada sistem sosial dan nilai budaya masyarakat Mandailing. Modal sosial yang dibangun melalui sistem sosial budaya memperkuat kepercayaan terhadap tata kelola Badan Usaha Milik Desa sebagai upaya pemberdayaan ekonomi masyarakat di Mandailing Natal.
\end{abstract}

Kata kunci: pemberdayaan ekonomi; kepemimpinan; modal sosial; Badan Usaha Milik Desa (BUMDes)

\section{Introduction}

The development of regions and villages as Indonesia's development framework is a government Nawa Cita program that shows that overall development must pay attention to the smallest unit, namely the village, which is the driving force of Indonesia's progress. The village as the smallest unit of government 
is still often ignored in development because development only touches urban areas that are considered strategic, profitable, and prospective. It leads to economic growth that can only be felt in urban areas. In fact, in essence, it aims to build self-reliance development for the people and make room for both rural and urban communities to be involved and feel the impact of the development. This phenomenon has resulted in the emergence of the development gap between rural and urban. Therefore, in line with the government's Nawa Cita agenda to realize equitable development, Law Number 6 of 2014 concerning Villages (constitution about village law) was formulated to coordinate the village government system. If referring to the rules, it shows that village development aims to improve rural communities' welfare, reduce poverty by meeting basic needs, develop village facilities and infrastructure, develop local economic potential, and sustainably utilize natural and environmental resources. To achieve the rules' development goals, the government adopted a new approach to moving the economy in rural areas by establishing village-owned enterprises or Badan Usaha Milik Desa (BUMDes), managed entirely by village communities.

The establishment of village-owned enterprises is one of the Nawa Cita programs, which are expected to increase the economy, welfare, and income of rural communities and original village income and create jobs. Through the establishment of village-owned enterprises, the village government and the community are allowed to map the potential of village resources and strengthen village economic institutions through the village's characteristics and the characteristics and the needs of the community itself (Prasetyo 2016). Therefore, village-owned enterprises are a strategic development program and community empowerment instrument (Anggraeni 2016).

Community empowerment as one of the efforts to realize national development must consider three key concepts: participation, planning that is prepared based on the interests and needs of the community, and the community's potential strength. The potential developed in establishing businesses developed in the village in realizing economic strengthening can be established through family or community based on social institutions, namely: households, mosques, colleges, and institutions or other community institutions (Amalia \& Syawie 2015). It is in line with the village-owned enterprises as an economic strengthening institution for rural communities. In the establishment of village-owned enterprises, institutions, in this case, the village head, village consultative body, village officials, and community members, are represented as figures or people worthy of representing their citizens.

Nevertheless, in reality, the village-owned enterprises that have been established in North Sumatera include 936 villages (Badan Penelitian Dan Pengembangan Provinsi Sumatera Utara 2018), and there are 436 villages in North Sumatera that have not been able to utilize the potential of natural resources and village potential (Khairani et al. 2019). Nevertheless, village-owned enterprises' management still uses social institutions to collect community aspirations in determining the type of business and mapping the local potential that will be developed to empower the community to improve and improve the economy. In this case, the success of community economic empowerment can be examined through the social capital approach. According to Putnam (1995), social capital represents community involvement in providing benefits through collective actions, where social capital comes from the relationship between people in certain groups in society. Hasbullah (2006) also suggested six main social capital elements: participation in a network, reciprocity, trust, social norms, values, and proactive action.

The successful practice of social capital in managing village-owned enterprises and becoming a role model for other village-owned enterprises outside Java Island is shown by village-owned enterprises in Ponggok Village, Polanharjo Districts Klaten District. In the practice of managing village- owned enterprises in Ponggok Village, manifestations of social capital practiced in management are networks, beliefs, and norms (Santi \& Wulandari 2018). Meanwhile, in other places, such as village- owned enterprises Surya Sejahtera in Kedungturi Village, Sidoarjo District, the development strategy is carried out through various aspects, namely participation, reciprocity, trust, social norms, honesty values, and proactive action (Adawiyah 2018). These social capital aspects are manifested in survey feedback, education and training activities, team building, and management objectives. Furthermore, according to 
Kirowati \& Setia (2018), the form of social capital practices in village-owned enterprises management can be realized through joint responsibility to strengthen trust and networks.

Human resources are one of the problems in developing social capital because people are pragmatic and tend to have instant and consumptive lifestyles, making it difficult to direct them to social activities. Therefore, external parties' existence is needed in supporting community economic empowerment programs starting from the most miniature social system at the village level or rukun warga (RW) for the welfare of the community (Sehabuddin et al. 2016). Social capital is seen as necessary in building society today's competitive and informative era (Andryani 2018). Likewise, the similarity of values and norms, the embodiment of cooperation, networks, and trust in the Coleman concept, is a bridge for creating social capital (Putra 2018). In a community whose collectivity has been built, social capital can foster initiatives and agreements among community members that strengthen their participation (Prasetyono et al. 2017). Although social capital components, such as networks, norms, and trust, are the main components, these must be adapted to the village's environmental, cultural, and socioeconomic conditions (Suranto \& Hardianto 2019).

Managing village-owned enterprises' problems are from internal aspects such as village community resources and ability to manage and problems in building relationships or networks with outside parties (Puspitasari 2015). Social capital has naturally been formed in community members through the same values and norms built based on the citizens' agreement; however, in the management of economic institutions such as village-owned enterprises, it is necessary to have the board's ability to build trustbased on mutually agreed values by achieving the vision and mission in an effort, improvement of the economy of its citizens. It is not practiced by village-owned enterprises Maju Bersama in Jawi-Jawi Village, Sei Kepayang Barat Districts. Even though these village-owned enterprises' management has contributed to the village, the network development and trust have not been good enough because of the lack of a network of cooperation built with third parties. Apart from that, the provision of loans with a determined interest rate is considered too high and equivalent to cooperatives around the village (Zulfahmi et al. 2020). It is not following village-owned enterprises' management principles, which cannot be a competitor with community businesses that have been established before.

The success of social capital-based village-owned enterprises management in its development can also be seen from the village-owned enterprises Tirta Mandiri in Ponggok Village through the manifestation of trust, namely community participation through providing open opportunities for the community to invest (Huruta et al. 2020). Social capital has a vital role in the successful management of village-owned enterprises, as researched by Rustinsyah (2019) in agricultural irrigation management, which impacts increasing agricultural production employment opportunities and nationally supporting national food security. Building social capital is achieved through mutual trust and agreement to apply the norms of identity and value of cooperation and open to building networks (Trisnanto et al. 2017).

In the case of maize agribusiness development in Tujuh Belas Sub-Districts, Bengkayang Districts, West Kalimantan, it shows the success of the application of social capital in farming practices through the exchange of economic resources, which are categorized into two, namely: exchange of resources between the institutions involved and the exchange of household labor (Sudrajat et al. 2015). Apart from social capital, there are supporting elements in village-owned enterprises' management, namely Regional Regulations and Village Regulations (Huruta \& Sasongko 2016).

In communities in coastal areas, there is a character of social capital through the management of dominant groups, namely community groups such as arisan, neighborhood, recitals, fishermen groups, and fisherwomen. This dominant group resides in the settlement's internal environment, and its members are residents of the settlement, and access to outside resources is limited, resulting in a high level of trust and solidarity among residents. Social capital is used to meet subsistence needs (Anggraini \& Agus 2018). Anggraini \& Agus (2018) find that if there is a dominant group in the internal environment, then there is a social capital strengthening scheme by strengthening the role of social institutions such as the 
village consultative, village community resilience institution, farmers group association (Gapoktan), family welfare empowerment, village-owned enterprises, and cooperatives (Cahyono \& Adhiatma 2012).

Meanwhile, Wibowo et al. (2016) see the dynamics of social capital for fishermen groups from collaboration in the economic sector that stimulates trust, norms, and strong networks. Gutiérrez et al. (2011) stated that on fishermen groups found that community-based co-management is practiced through collaboration between managers and fishers. The manager's role is an effort to improve the regulatory process to get the expected benefits. This co-management process has an impact on increasing the sense of ownership so that fishers feel a sense of responsibility for their catch, sensitivity, management based on local knowledge, decision-making systems based on collective values and norms, and compliance that arises due to encouragement of social control (Gutiérrez et al. 2011). Furthermore, Putnam (1995) revealed that social capital is a social organization feature, such as networks, norms, and beliefs that facilitate coordination and mutually beneficial cooperation. If the village-owned enterprises conduct economic empowerment through business development by revitalizing social capital in the community based on social and cultural systems, it can strengthen shared commitments through channeling aspirations, data collection, and mapping of community needs programs. Also, it is necessary to pay attention to the principles of governance in the development of BUMDes, namely: 1) cooperative, 2) participatory, 3) emancipatory, 4) transparent, 5) accountable, and 6) sustainable (Widiastuti et al. 2019).

Social capital as an approach used in seeing the success rate of social capital-based community economic empowerment through the implementation of village-owned enterprises will show how villageowned enterprises are implemented and managed jointly through the distribution of roles, authorities, responsibilities, and systems of appreciation and also shared attachments manifested in collective actions institutionalized and encouraged for the benefit of its citizens. This empowerment program developed jointly with the social capital approach must see the actors (the community to be empowered) and the main character (chairman) in the membership structure of the village- owned enterprises form specific actions to increase the sense of shared ownership that promotes the responsibility of the actors, sensitivity and increased regulation in better decision making and supervision by its members.

Collective actions in supporting shared goals as determined in village-owned enterprises' planning and establishment are more likely if the community's social capital is substantial. The social capital approach offered by Putnam (1995) is interesting to see how leaders in these village-owned enterprises become drivers to make active social capital to make regulations and encourage people to be empowered and provide mutual benefits. Social capital is necessary to strengthen the collaboration between stakeholders and researchers (Rustinsyah 2020). Therefore, this study wants to describe economic empowerment to strengthen social capital through village-owned enterprises.

\section{Research Method}

This study uses a qualitative research method with a participatory action research perspective. These methods and perspectives are chosen because their research is applied in solving specific problems. Research and action research in this paper focuses on strengthening rural communities' economy in Mandailing Natal Districts, North Sumatera Province. This research was conducted for two months, February to March 2020. Leadership in a community institution in the business management system in village-owned enterprises is carried out jointly by involving elements of the community that can make an essential contribution to the success of empowerment, accompanied by individual and community participation, social relations between fellow citizens, and the environment.

Gutiérrez et al. (2011) disclosed prominent community leaders and substantial social capital in the community could be combined with local resources to be used as their livelihood. The established research location included four villages in the Mandailing Natal Districts of North Sumatera. The four villages that are designated are representative villages seen from some determined indicators, namely: 
management, type of business and business potential, human resources, community participation, and also sustainable business potential. The villages which were the sample of the study consisted of Mondan Village, Hutanaingkan Village, Maga Lombang Village, and Aek Banir Village. In a cultural entity, Mandailing Natal District is bound to a cultural value system, namely the Mandailing culture. Research data mining was carried out by conducting in-depth interviews with six community members in each designated village (four villages) so that the total number of people interviewed was 24 people consisting of one person from the village government elements (village head or village secretary), one member of the village consultative and four community representatives from each village.

\section{Results and Discussion}

\section{Engagement and public participation in the village-owned enterprises implementation}

Village-owned enterprises is a business entity whose entire or most of its capital is owned by the village through direct participation from separated village assets in order to manage assets, services, and other businesses for the maximum welfare of the village community (Article 1 Number 6 of the Village Law to Article 1 point 2 Regulation of the Minister of Villages for Disadvantaged Areas and Transmigration Number 4 of 2015 concerning Establishment, Management and Management, and Disbanding of VillageOwned Enterprises/Permendes Number 4/2015). Village-owned enterprises, as social institutions, sides with the community's interests through their contribution to the provision of social services, with other objectives in the context of increasing the village's original income. Meanwhile, as a commercial institution, it aims to seek profit through the supply of local resources (goods and services) to the market (Ridlwan 2014).

In addition to the administrative entity under Mandailing Natal, four villages, the research sample is also engaged in a cultural unity, namely Mandailing culture. In the unity culture, the Mandailings confirmed the existence itself based on the shared culture that became the foundation for the citizens to structure social life. Therefore, the strengthening of social capital is built by the citizens on the social aspect as citizens under a particular government and as a social group bound to a cultural order. It is in line with what was stated by Suranto \& Hardianto (2019) that the strength of internalized social capital through the social aspects that characterize a community group must be adjusted to the village's cultural conditions and socioeconomic environment. Therefore, social capital is built on shared values that boost culture and attachment to the order of values and cultural norms that exist to organize the citizens through a system of cultural values and kinship system adopted by the citizens. It can be attributed to how the process of forming village-owned enterprises-informing village- owned enterprises village governance, captures the aspirations of its citizens through village meetings involving the village consultative, community leaders and cultural figures, and representatives of women's groups. In this deliberation activity, apart from discussing and collecting various inputs related to the type of business to be held, personnel assigned by the management, and village-owned enterprises participation capital, the criteria for selecting village-owned enterprises administrators and managers are adjusted to human resources conditions in each village.

Communities who have been involved since the planning process are demonstrated through residents' participation in formulation and planning meetings for the establishment, determination of the type of business, and administrators' appointment in the four villages. From the interviews conducted with 24 communities in four villages determined by the accidental sampling method, it can be explained that community involvement and participation can be grouped as follows: 1) some $45.8 \%$ of the community are aware of the village-owned enterprises and are involved in planning, 2) a total of $16.7 \%$ were aware of the village-owned enterprises and were not involved, and 3) a total of $37.5 \%$ were not aware of the village-owned enterprises and were not involved. From these results, it can be shown that the community was involved from the establishment process to the development of village-owned enterprises, although it was not maximized because there were still people who did not know of village-owned enterprises in their village. Determining the type of business managed by each village has reflected the village's potential by the natural geographic features, residents of rural communities in managing the business, 
and citizens' need to be products business carried on. It is seen that village-owned enterprises run this type of business in every village, as outlined in Table 1.

Table 1.

Type of business village-owned enterprises in Mandailing Natal

\begin{tabular}{|c|c|c|c|c|}
\hline $\begin{array}{l}\text { Village-owned } \\
\text { enterprises name }\end{array}$ & Type of business & Village & Sub-District & Districts \\
\hline \multirow{2}{*}{ Harapan Kita } & Cattle breeding & \multirow{2}{*}{ Mondan } & \multirow{3}{*}{ Hutabargot } & \multirow{6}{*}{$\begin{array}{l}\text { Mandailing } \\
\text { Natal }\end{array}$} \\
\hline & Making the Compost & & & \\
\hline Sumber Rezeki & Cattle breeding & Hutanaingkan & & \\
\hline \multirow{2}{*}{ Mitra Warga } & Depot mineral water & \multirow{2}{*}{ Maga Lombang } & \multirow{2}{*}{$\begin{array}{l}\text { Lembah } \\
\text { SorikMerapi }\end{array}$} & \\
\hline & Decor Party Supplies & & & \\
\hline Serba Indah & $\begin{array}{l}\text { Preparation of Palm } \\
\text { Sugar }\end{array}$ & Aek Banir & Panyabungan & \\
\hline
\end{tabular}

Source: Primary research data

Management type of business in every village has involved the villagers' participation as implemented in Mondan and Hutanaingkan, which sets the type of business as breeding cattle. Such determination has been attentive to the situation of social and natural conditions. The public is allowed to be involved in the management of cattle breeding. The system is open for citizens who accept the system established by the village-owned enterprises board. Communities can take advantage of widely available open land around their villages. Citizens around would make cattle farming their second job other than being a farmer. That means keeping cattle has become a habit in the lives of the residents in Mondan Village, and Hutanaingkan Village. Because of the social system, a cow can symbolize the residents' social status and material ownership status. The residents do maintenance and breeding of cattle, and the cow manure waste is abundant in the village, so that the citizens have the initiative to propose a plan of composting as a kind of business that developed after the breeding of cattle.

In contrast to the Mondan Village and Hutananingkan Village, Maga Lombang Village chose the type of business, and the drinking water depot leasing party supplied the tools. Selection of the type of business, depot drinking water, has become a critical need for the villagers because groundwater is not suitable. The party lease fittings are defined as a type of business developed to give the village youth groups more opportunities to engage in rural enterprises' development. Village-owned enterprises administrators and managers in this village or the village involve a group of teenagers known as Naposo Nauli Bulung, a unity of teenage sons and daughters engaged in a cultural value system of Mandailings. Therefore, Naposo Nauli Bulung social capital for residents of surrounding communities in doing village-owned enterprises business while still preserving the cultural values that exist in the village.

The management model in this village shows how the involvement of social organization groups in youthbased villages is an effort to increase the types of youth-based businesses. In this group, a coordinator is appointed as the person in charge. Giving trust to youth groups in managing village- owned enterprises business types further strengthens and stimulates trust and a sense of ownership among fellow citizens based on the system of values and norms in the Naposo Nauli Bulung group system. It is in line with the model developed by Gutiérrez et al. (2011) regarding co-management. Also, it shows that social organizations or social unit units in society have played a role in the development of village-owned enterprises, as disclosed by Cahyono \& Adhiatma (2012).

The Aek Banir Village has a potential natural supply of forest plants that citizens can use, and local plants are available in the village, such as palm trees known by local communities as Arenga Pinnata. Almost all of these trees can be used by citizens, ranging from fruits, leaves, and stems. However, the selected type of village-owned enterprises is palm sugar manufacture. Selection is based on the analysis 
of natural conditions and surrounding residents. The citizens have the ability and potential to treat water that is extracted from the stem palm sugar tree known as sap water. Utilization of sap water taken from palm tree tapping process has been conducted as an additional livelihood of its citizens. From the results of these intercepts, community residents make palm sugar in solid form. As stated in the act, the establishment of village-owned enterprises should not turn off the local community effort, so that the manufacture of ant sugar (powdered brown sugar) is the right choice because, with the type of business that village-owned enterprises manage, the business community around is not threatened. The system implemented by the village-owned enterprises' board manages the manufacture of ant sugar did not ignore the surrounding community. By purchasing a system sap from the citizens at a purchase price higher than that of competitors, the community has been empowered by village-owned enterprises.

Community involvement and participation can also be shown through the criticism and suggestions given to village-owned enterprises managers. The manager openly accepts suggestions and input given by the residents of the surrounding community. Through the received suggestions and input, the village-owned enterprises' manager conducts analysis and evaluates the management system that has been implemented. The manager also knows the community's perceptions and evaluations of the implementation of the village-owned enterprises.

The description of involvement and public participation in implementing the fourth village-owned enterprises in the village shows government officials and administrators. Village-owned enterprises have considered various social and cultural aspects of their people. It can be seen from how the various operations defined and implemented openly provide an opportunity to proactively engage directly and provide benefits through activities and measures for rural communities' economic empowerment. Additionally, the village-owned enterprises' board's initiation does not ignore the existence of women's groups, or young men are bound in cultural values, such as Naposo Nauli Bulung, which have been empowering the youth to participate in the economic empowerment of the village.

\section{The forms of business empowerment in village-owned enterprises}

A system of relations between citizens bound in the system of values and cultural value system can determine the relationship awakened in its citizens' lives. In village-owned enterprises implementation, there are several elements involved, namely the village head and village consultatıve under the auspices of village governance institutions that act as a facilitator in the development of village-owned enterprises. In this case, the village chief, by Village Law, has a role as an advisor. An advisor in the village-owned enterprises institutional system, the village head, entrusts the overall management to the community's mutually agreed upon management. As a result of research (Prafitri et al. 2018), village heads' role in village-owned enterprises' success can be seen from the management of village economic institutions through intense involvement in the formulation, preparation, and dissemination of developed business plans. In terms of the delegation of authority, the village head fully entrusts the duties and responsibilities to the village-owned enterprises' management by implementing transparency, control of accountability for management and reporting systems, accounting audits, and participation and cooperation stakeholders.

The research results found that the village head and village consultative showed involvement both formally and informally. Formal involvement has been seen since the village-owned enterprises' establishment process, such as establishing meetings, determining capital participation, and determining village-owned enterprises' management's composition. However, in implementing village-owned enterprises, the village head and village consultative roles show more informal involvement. If it is related to the social capital built up between community members, then non- formal involvement is more accepted by the community members because there is a critical value system among its citizens.

It can be seen from the elements of social capital formed in the village, including solidarity, networking, cooperation, and the cooperation system. The elements of social capital have formed an institutional life order. Although the village head and village consultative in the village-owned enterprises' 
management system are advisors, formally, the two institutions are not considered carrying out their duties and responsibilities properly. However, in a non-formal manner, as indicated in the elements of social capital, the two institutions have carried out their function as advisors for the implementation of village-owned enterprises. The relationship that is built based on cultural values held by citizens is more prominent. The village head and consultative body are considered representations of community leaders who have the right to lead. The village head and the community's consultative body are usually community leaders represented through particular institutions, such as religious institutions (Ulama/ Kyai) and educational institutions (teachers). These institutions culturally have social norms used as a guide in carrying out all their activities, which are used as supporters of success to accommodate their communities in implementing empowerment activities. However, these established institutions foster a sense of collectivity based on shared values, norms, and a system of cooperation and trust (Putra 2018).

The socio-cultural society still places social institutions in interaction, and the system of social relations is patronage. This patronage relations system is manifested in a pattern of vertical relations between two parties, namely those in high social status (patron) and low social status (clients). In another sense, this system of patronage relations involves both parties, bound in a relationship of morality, characterized by the parties' social status. Through this relationship of morality, mutual benefit or reciprocity is realized by exchanging roles that mutually benefit the two parties. Parties of high social status can use the influence and resources they have to encourage lower parties to provide specific supports.

The patronage relationship system representing this social status can not only be measured from an economic system that is material in nature. In the cultural value system, this is realized through kinship and social systems, namely Dalihan Na Tolu, which is etymologically interpreted as "The Three Stacks." Dalihan Na Tolu's meaning in the Mandailing community is the position and role according to customs and refers to the genealogical system (blood relations) and marriage. Three positions can explain this social system's position and role, namely mora (girl giver) and anak boru (girl recipient); these two groups are formed based on marital ties. At the same time, kahanggi (brother) is a group formed from blood ties. It can describe the position of these three groups as in Figure 1.

This Dalihan Na Tolu social system is practiced from the implementation of the community's customs. However, this social system relationship that has been positioned in the Dalihan Na Tolu system can also influence social relations among the people because the system is a reference and foundation in the social system. Role and position in the Dalihan Na Tolu kinship system are not permanent. Its position can change according to the customary program being carried out. The role and highest position in this kinship system is mora. The mora group in the Dalihan Na Tolu system is the most respected and privileged person.

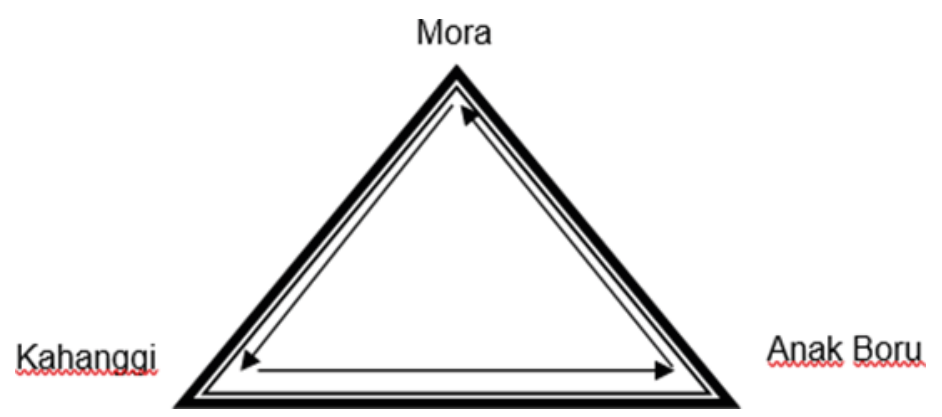

Figure 1.

Dalihan Na Tolu of Mandailings

Source: Image modified by authors from Gultom (2017)

This social system will also impact village-owned enterprises managers, village leaders, and community members in its implementation. Although the village-owned enterprises' implementation is not related to the conventional value system that is practiced, this kinship system remains the norm for functionally constructed interactions and relations that guide the rules, controls, and directives on the behavior 
actions of Mandailing communities. In looking at community relations with the leadership system, they show collective actions because social capital can come from relationships between people in certain groups, which refer to the social system and the community's cultural values. The realization of the relationship between village-owned enterprises managers and community members who actualize the social system and customary norms of the Mandailing community can be demonstrated from villageowned enterprises' management practices.

Since its inception, village government officials have carried out implementation systems and procedures in an orderly administration, such as village-level deliberations involving village government and several community elements, such as community leaders, traditional leaders, religious leaders, NGOs, and parties considered representative. However, these community representatives' presence is present as a symbolic invitation and in the social and cultural system of the Mandailing community. The figures invited and present have crucial social status and roles in providing joint decision-making views in public. If the Dalihan Na Tolu practice is applied in a village-level meeting, each character's status, especially those who have a mora status in the system of kinship with the participants in attendance, then, of course, the norm system will automatically and sometimes accidentally be practiced. It is actualized through attitudes, actions, and words of words conveyed at the meeting.

The village chief and consultative body's existence is actualized in non-formal meetings in mosques, stalls, or places used as a public space. This space is used to discuss and deliver various things encountered by citizens, particularly village-owned enterprises' implementation. So the village chief has to follow through by initiating meetings officially held at the village office to resolve the problems encountered in the village-owned enterprises implementation, which involves the consultative body, village-owned enterprises administrators, companion village, and representatives from the community.

The system describes that social life is a vital leadership role in strengthening and maintaining social capital. People prefer to get comfort to convey various problems encountered in non-formal situations. The public accepts the relationship built on the non-formal situation because it is part of the cultural value system that has received them from generation to generation. The meetings take place in the public space into a melting pot of various interests, with the existence of leaders represented by institutions in society more as a place for the community. Leaders' role presented in the non-formal situation generally has more real influence in building and maintaining social capital.

\section{Social capital in village-owned enterprises implementation}

In the order of the social life of the Mandailing community, there are social norms that become references or guidelines in interacting and acting for their citizens. This social norm is manifested in citizens' behavior and actions, which have been determined based on the agreement to become a guideline that must be implemented from generation to generation. Therefore, this social norm can be used as a basis for various activities carried out by the community. The social norms formed among the citizens of Mandailing are inseparable from the traditional system that has been formed, one of which is the Dalihan $\mathrm{Na}$ Tolu system. In addition to regulating social relations, specifically in the three positions and roles of kinship systems, this cultural value system also regulates the system of relations in the context of broader kinship. In such a kinship system, the Mandailing community makes it a reference to obedience in social relations.

The Dalihan Na Tolu value system in Putnam's (1995) concept is seen as a stimulus to collective actions. Therefore, the activities carried out are oriented toward reciprocal relationships, trust, social norms, and trust, expressed by Hasbullah (2006). The establishment of a village-owned enterprises business in the village provides an opportunity for the community to be involved directly or indirectly. Direct community involvement can be shown from village-owned enterprises' business products or villageowned enterprises managers involving the community in product management. The development of village-owned enterprises' superior products in Mandailing Natal shows an effort to explore the village's 
potential and residents' needs. Some of them are Mondan Village, Hutabargot Districts, where the villageowned enterprises business is breeding cows and making compost. In this village, the livelihoods of the residents are dominated by farmers and owning livestock. Therefore, making compost is taken from livestock manure owned by the residents, processed into fertilizer by village-owned enterprises, then distributed back to the surrounding community at a more affordable price than the market price. The system for monitoring and raising livestock by village-owned enterprises managers is given openly to residents who desire and can look after and supervise cattle bred by village-owned enterprises.

With this model, village-owned enterprises managers and the community have built a trust system among their citizens. In another village that produces ant sugar, namely Aek Banir Village, the community is a producer of brown sugar. The village potentials are plantations and, of course, sap water from the enau or aren (Arenga pinnata) trees that grow around the village without the need to be planted. The juice taken from the palm tree will be cooked and produced into brown sugar. Aek Banir Village, which has village-owned enterprises called Serba Indah village-owned enterprises, sees the potential that exists in the village. Even though the residents have independently produced their brown sugar, the Serba Indah village-owned enterprises business's existence will certainly not stop the residents' efforts. The existence of village-owned enterprises empowers residents' economies by buying raw sap water and brown sugar products that community members have produced at a slightly higher price than collectors or brokers. These examples show that the social system built from village-owned enterprises management and village-owned enterprises product developments must be oriented toward mutual interests that can encourage economic empowerment for the community, which will impact a mutually beneficial social network.

In the implementation of village-owned enterprises, community beliefs grew on the encouragement of social norms and relations built based on the cultural value system of the Mandailing community. It strengthens the citizens' belief and solidarity in village-owned enterprises' development through the chosen management team. Community belief is also shown through the residents' appreciation by supporting various activities related to village-owned enterprises. Community belief greatly encourages business development managed by village-owned enterprises. However, village-owned enterprises have not yet reached the pilot stage of business development through their citizens' investment funds.

\section{Conclusion}

Community empowerment as one of the efforts to achieve national development, in essence, must consider the three key concepts, namely participation, planning, and arranged on the interests and needs of citizens and organized potential power of the community. Through the implementation of villageowned enterprises in Mandailing Natal, economic empowerment shows some social capital elements in village-owned enterprises' implementation.

First, community involvement and participation are large enough so that $45.8 \%$ of people claimed to know their village-owned enterprises in the village and were involved in the planning, establishment, and establishment of village-owned enterprisesdeveloped businesses. Additionally, the village-owned enterprises' board's initiation does not ignore the existence of women's groups or young men bound in cultural values such as Naposo Nauli Bulung, which has empowered the youth to participate in the economic empowerment of the village. Second, relationships between village-owned enterprises managers, village leaders, and citizens in the implementation of village-owned enterprises are built on the social system and cultural values of Mandailing society, Dalihan Na Tolu. This system emphasizes kinship in the Dalihan Na Tolusystem to become the norm for the community's interactions and relationships.

Third, social norms and beliefs of the village-owned enterprises' implementation. Social norms and community belief cannot be separated from social norms and relationships, which refer to the social system and cultural values of the Mandailing community. Social norms and relationships that work 
strengthen public confidence in the implementation of village-owned enterprises. Before the existence of village-owned enterprises, social capital was practiced in community life in Mandailing Natal. Its existence strengthens the implementation of community empowerment through a village economic institution managed through village-owned enterprises. The social and cultural system that has been acculturated in the community strengthens social capital, especially trust in business development managed by village-owned enterprises. The community must fully support village-owned enterprises' sustainability in managing and developing business units.

\section{References}

Adawiyah R (2018) Strategi pengembangan Badan Usaha Milik Desa (BUMDes) berbasis aspek modal sosial (Studi pada BUMDes Surya Sejahtera, Desa Kedungturi, Kecamatan Taman, Kabupaten Sidoarjo). Thesis, Universitas Airlangga, Surabaya.

Amalia AD \& Syawie M (2015) The development of rural resilience with empowering concept: A study of sociological perspective. Sosio Informa 1 (2):175-188. https://doi.org/10.33007/inf.v1i2.146.

Andryani AK (2018) Modal sosial pada masyarakat nelayan Pa'bagang di Desa Bontosunggu Kabupaten Kepulauan Selayar. Thesis, Universitas Negeri Makassar, Makassar.

Anggraeni MRRS (2016) Peranan Badan Usaha Milik Desa (BUMDes) pada kesejahteraan masyarakat pedesaan studi pada BUMDes di Gunung Kidul, Yogyakarta. Modus 28 (2):155. https://doi. org/10.24002/modus.v28i2.848.

Anggraini O \& Agus M (2018) Penguatan modal sosial berbasis kelembagaan lokal masyarakat pesisir perspektif gender di Kabupaten Bantul. JSEP (Journal of Social and Agricultural Economics) 11 (2):11. https://doi.org/10.19184/jsep.v11i2.6889.

Badan Penelitian Dan Pengembangan Provinsi Sumatera Utara (2018) Hasil kelitbangan. [Accessed 19 January 2019]. http://balitbang.sumutprov.go.id/website/hasil_kelitbangan.

Cahyono B \& Adhiatma A (2012) Peran modal sosial dalam peningkatan kesejahteraan masyarakat petani tembakau di Kabupaten Wonosobo. Conference in Business, Accounting, and Management (CBAM) 1 (1):131-144.

Gultom AF (2017) Refleksi konseptual Dalihan Na Tolu dan Porhalaan pada etnis Batak Toba dalam perspektif kosmologi dalam filsafat Islam: Historitas dan aktualisasi (peran dan kontribusi filsafat Islam bagi bangsa). Yogyakarta: Yogyakarta-FA Press.

Gutiérrez NL, Hilborn R, \& Defeo O (2011) Leadership, social capital and incentives promote successful fisheries. Nature 470 (7334):386-389. https://doi.org/10.1038/nature09689.

Hasbullah J (2006) Social Capital (Menuju Keunggulan Budaya Manusia Indonesia). Jakarta: MRUnited Press.

Huruta AD, Kundhani EY, \& Manurung CR (2020) The development of village-owned enterprises: Lessons learned from Ponggok Village. Masyarakat, Kebudayaan dan Politik 33 (1):77. https:// doi.org/10.20473/mkp.v33i12020.77-86.

Huruta AD \& Sasongko G (2016) Uang dan ruang yang berkelanjutan dalam pembentukan Badan Usaha Milik Desa (BUMDes). Masyarakat, Kebudayaan dan Politik 29 (4):212. https://doi. org/10.20473/mkp.v29i42016.212-222.

Khairani L, Ramlan, Hayati, \& Pulungan DR (2019) Penguatan kelembagaan BUMDes Karya Tanjung di Desa Tanjung Pasir Kabupaten Langkat. In: Seminar Nasional AvoER XI, 1 October 2019, Palembang. Universitas Sriwijaya: Seminar Nasional AvoER XI, 23-24.

Kirowati D \& Setia LD (2018) Pengembangan desa mandiri melalui BUMDes dalam meningkatkan kesejahteraan masyarakat desa (Studi kasus: Desa Temboro Kecamatan Karas Kabupaten Magetan). Jurnal AKSI (Akuntansi Dan Sistem Informasi) 2 (1):15-24. https://doi.org/10.32486/ aksi.v2i1.213.

Prafitri N, Setyoko PI, \& Puspita DR (2018) The business management of the village government in managing village owned enterprise. Masyarakat, Kebudayaan dan Politik 31 (3):328.

Prasetyo RA (2016) Peranan BUMDes dalam pembangunan dan pemberdayaan masyarakat di Desa Pejambon Kecamatan Sumberrejo Kabupaten Bojonegoro. Jurnal Sosiologi Dialektika 11 (1):86100. 
Prasetyono DW, Astuti SJW, Supriyanto, \& Syahrial R (2017) Pemberdayaan petani berbasis modal sosial dan kelembagaan. AJIE-Asian Journal of Innovation and Entrepreneurship 2 (3):231-238.

Puspitasari DC (2015) Modal sosial perempuan dalam peran penguatan ekonomi keluarga. Jurnal Pemikiran Sosiologi 1 (2):69. https://doi.org/10.22146/jps.v1i2.23445.

Putnam RD (1995) Bowling alone: America's declining social capital. Journal of Democracy 6 (1):6578.

Putra BS (2018) BUMDes AL-Madina dalam perspektif modal sosial James S. Coleman. Thesis, Universitas Airlangga, Surabaya.

Ridlwan Z (2014) Urgensi Badan Usaha Milik Desa (BUMDes) dalam pembangun perekonomian desa. Fiat Justisia 8 (3):424-440. https://doi.org/10.25041/fiatjustisia.v8no3.314.

Rustinsyah (2019) Social capital in agricultural irrigation management of "RBUMDES Mursapa". Masyarakat, Kebudayaan dan Politik 32 (2):123-133.

Santi SK \& Wulandari T (2018) Peran modal sosial dalam pengelolaan Badan Usaha Milik Desa (BUMDES) di Desa Ponggok Kecamatan Polanharjo Kabupaten Klaten. Social Studies 7 (2):145157.

Sehabuddin U, Warcito W, \& Sadiah S (2016) Modal sosial dalam proses pemberdayaan masyarakat di Kota Bogor, Cianjur, dan Sukabumi. Jurnal Manajemen 7 (1):29-38.

Sudrajat J, Mulyo JH, Hartono S, \& Subejo (2015) Peranan social capital dalam memelihara keberlanjutan agribisnis jagung. Masyarakat, Kebudayaan dan Politik 28 (3):139-152.

Suranto A \& Hardianto FN (2019) Model konseptual hubungan modal sosial dan kinerja BUMDes. In: Management Dynamic Conference 5 (MADIC 5), 3 September 2019, Semarang. Universitas Stikubank: Seminar Nasional dan Call for Papers 2019, 214-220.

Trisnanto TB, Fitriani, \& Fatih C (2017) Building social capital for farmer association. Masyarakat, Kebudayaan dan Politik 30 (10):59-67.

Wibowo JT, Kinseng RA, \& Sumarti T (2016) Dinamika modal sosial nelayan dalam arena ekonomi: Studi kasus nelayan rajungan Desa Betahwalang, Kecamatan Bonang, Kabupaten Demak. Jurnal Sosiologi Reflektif 11 (1):139. https://doi.org/10.14421/jsr.v11i1.1276.

Widiastuti H, Putra WM, Utami ER, \& Suryanto R (2019) Menakar tata kelola Badan Usaha Milik Desa di Indonesia. Jurnal Ekonomi dan Bisnis 22 (2):257-288. https://doi.org/10.24914/jeb.v22i2.2410.

Zulfahmi Z, Badaruddin B, \& Humaizi H (2020) Peran modal sosial dalam pengelolaan Badan Usaha Milik Desa Maju Bersama di Desa Sei Jawi-Jawi Kecamatan Sei Kepayang Barat Kabupaten Asahan. Perspektif 9 (2):168-182. https://doi.org/10.31289/perspektif.v9i2.3346. 